\title{
THE POTENTIAL OF HEDYOTIS CORYMBOSA (L.) LAMK EXTRACT TO INHIBIT THE PROGRESSIVITY OF ORAL CANCER CELL IN RATS INDUCED WITH BENZOPYRENE
}

\author{
(POTENSI EKSTRAK HEDYOTIS CORYMBOSA (L) LAMK DALAM MENGHAMBAT \\ PROGRESIFISITAS SEL KANKER MULUT PADA TIKUS YANG INDUKSI \\ DENGAN BENZOPYRENE)
}

\author{
Theresia Indah Budhy, Istiati, Bambang Sumaryono \\ Department of Oral Pathology and Maxillofacial \\ Faculty of Dentistry, Airlangga University \\ Jl. Mayjend. Prof. Dr. Moestopo 47 Surabaya 60132, Indonesia \\ E-mail: terebudhy@gmail.com
}

\begin{abstract}
Cancer is still ranked as the fifth cause of mortality and morbidityin Indonesia.Hedyotis corymbosa (L.) Lamk has ursolat acid as anti-proliferative cancer cell. This research is aimed to determine the potency of Hedyotis corymbosa (L.) Lamk at different doses, namely 375,750 , and $1500 \mathrm{mg} / \mathrm{kg}$, used as an inhibitor for the progressivity of oral cancer, such as proliferation, angiogenesis, and apoptosis of cancer cells. Post test only control group design was used in this research. There were 24 Rattus novergicus used as research samples. Those were divided into four groups, namely control, treatment group 1 with a dose of $375 \mathrm{mg} / \mathrm{kg}$, treatment group 2 with a dose of $750 \mathrm{mg} / \mathrm{kg}$, and treatment group 3 with a dose of $1500 \mathrm{mg} / \mathrm{kg}$. Their oral cavity was induced intramusculary by benzopyrene with a dose of $8 \mathrm{mg} / \mathrm{kg}$ for 4 weeks (twice a week) to create cancer. Hedyotis corymbosa (L.) Lamk was given orally for 10 days. All samples were aclimatitation to perform Histo Pathology Anatomi among groups. Haematoxillin Eosin for proliferation cancer cell and capilary. Immunohistochemistry for expression of caspase3. Data were tabulated andanalyzed statistically by ANOVA. There was significant difference of cancer cell proliferation and capilary between control and treatment groups. The most significant decreasing of cancer cell proliferation was in those samples given with a dose of $750 \mathrm{mg} / \mathrm{kg}$. Meanwhile, the highest apoptosis of caspase 3 expression was in those samples given with a dose of $750 \mathrm{mg} / \mathrm{kg}$. It can be concluded that Hedyotis corymbosa (L.) Lamk extract could decrease cancer cell proliferation and capilary as well as could increase apoptosis.
\end{abstract}

Key words: Hedyotis corymbosa (L.) Lamk, oral cancer, apoptosis, benzopyrene

\begin{abstract}
Abstrak
Kanker masih sebagai penyebab kelima mortalitas dan morbiditas di Indonesia. Hedyotis corymbosa (L.) Lamk memiliki asam ursolat sebagai anti-proliferasi sel kanker. Penelitian ini bertujuan untuk mengetahui potensi Hedyotis corymbosa (L.) Lamk pada dosis yang berbeda, yaitu 375, 750, dan $1500 \mathrm{mg} / \mathrm{kg} \mathrm{BB}$, sebagai inhibitor progresivitas kanker mulut, seperti proliferasi, angiogenesis, dan apoptosis sel kanker. Dalam penelitian ini digunakan Post test only control group. Terdapat 24 ekor Rattus novergicus sebagai sampel penelitian, dibagi menjadi empat kelompok, yaitu kontrol, kelompok perlakuan 1 dosis $375 \mathrm{mg} / \mathrm{kg}$, kelompok perlakuan 2 dosis $750 \mathrm{mg} / \mathrm{kg}$, dan kelompok perlakuan 3 dosis $1500 \mathrm{mg} / \mathrm{kg}$. Mukosa rongga mulut diinduksi intramuskuler dengan benzopyrene dosis $8 \mathrm{mg} / \mathrm{kg}$ selama 4 minggu sampai terbentuk kanker. Hedyotis corymbosa (L.) Lamk diberikan secara oral selama 10 hari. Dilakukan pemeriksaan Histopatologi, untuk proliferasi sel kanker dan pembuluh darah menggunakan Hematoksilin Eosin, sedangkan ekspresi caspase3 dengan Imunohistokimia. Data dianalisis secara statistik dengan Anova. Hasil didapatkan perbedaan signifikan proliferasi sel kanker dan pembuluh darah antara kontrol dan kelompok perlakuan. Dosis yang terbaik adalah $750 \mathrm{mg} / \mathrm{kg}$ terhadap penurunan proliferasi sel kanker, pembuluh darah. Pada ekspresi caspase 3 tertinggi diberikan dengan dosis $750 \mathrm{mg} / \mathrm{kg}$. Dapat disimpulkan bahwa Hedyotis corymbosa (L.) Lamk ekstrak dapat menurunkan proliferasi sel kanker dan pembuluh darah serta dapat meningkatkan apoptosis.
\end{abstract}

Kata kunci: Hedyotis corymbosa (L), kanker mulut, apoptosis, benzopyrene 


\section{INTRODUCTION}

The highest cause of mortality and morbidity in the world today is cancer. In Indonesia, cancer is ranked as the fifth cause of mortality. ${ }^{1}$ In the United States, $3 \%$ of 1 million cases in each year are related with cancer disease in oral cavity and oropharynx. ${ }^{2}$ Some intensive cancer treatments have been made including surgery, chemotherapy, radiation, immunetherapy, and pharmacotherapy, but they still have not given satisfactory results. Thus, alternative cancer treatments are very important. One of them is derived from Hedyotis corymbosa (L.) Lamk plant, known as apotential anti-cancer. Febriansah said that Hedyotis corymbosa (L.) Lamkextract has antiproliferative effects against liver cancer cells, but its effect on oral cavity cancer is still not known. ${ }^{3}$

Free radical compounds are highly reactive to the cells of the body causing mutations in "protooncogenes" and "suppressor genes" that contribute to the regulation of cell proliferation and apoptosis. It means that if there is a mutation in the gene, proliferation will be uncontrolled and apoptosis will be inhibited initiating cancer incidence. ${ }^{4,5}$ Cancer can also form its own blood vessels or angiogenesis in order to grow more progressive. ${ }^{6}$ Thus, it can be said that the imbalance between proliferating and both apoptotic cells and angiogenesis process makes can-cer become increasingly progressive.

Hedyotis corymbosa (L.) Lamk is more known to the public as a wild plant. It has a group of terpenoid compounds that can be used as a herbal drug. ${ }^{7}$ The terpenoid compounds contain ursolic acid that can inhibit liver cancer at a dose of $750 \mathrm{mg} / \mathrm{kg}^{8}{ }^{8}, 9$ Ursolic acid can interfere with the regulation of the cell cycle by inhibiting the cell cycle from the $G$ phase to the $S$ phase to inhibit cell proliferation. ${ }^{10}$ In addition, a research ${ }^{11}$ showed that ursolic acid can cause progressive barriers to gastric cancer cellcycle by in-activating cyclin/cdks. Ursolic acid also induces apop-tosis in the extrinsic pathway through TRAIL or tumor necrosis factor-related apoptosis inducing ligand. TRAIL works specifically to induce apoptosis in cancer cells, but not in normal cells. Ursolic acid then will activate caspase that has a function as a pro-apoptosis enzyme. ${ }^{12}$ In angiogenesis, ursolic acid contains of Hedyotis corymbosa (L.) Lamk has a role in inhibiting ERK pathway ${ }^{13}$ and in inhibiting the expressions of $V E G F$ and $b F G F .^{14}$

Therefore, this research aimed to determine the potential of Hedyotiscorymbosa (L.) Lamk extract as the inhibitor of the progression of oral cancer cells and as anti-proliferation of cancer cells in increasing apoptosis through caspase 3 expression and in de- creasing the number of new blood vessels. Finally, this research is expected to be used to develop oral cancer treatment.

\section{MATERIALS AND METHODS}

This research was a laboratory experimental research with post test only control group design. In this research, there were four groups, namely Treatment Group 1, Treatment Group 2, Treatment Group 3, and Control Group. The samples of this research were healthy male Rattus novergicus Wistar aged 2-3 months old and weighed 160-200 grams. In this research, replication was conducted as many as six times for each treatment. Hedyotis corymbosa (L.) Lamkextract was used with three different doses, namely $375 \mathrm{mg} / \mathrm{kg}, 750 \mathrm{mg} / \mathrm{kg}$, and $1500 \mathrm{mg} / \mathrm{kg}$.

Moreover, Hedyotis corymbosa (L.) Lamk extract was made with the following procedures. First, Hedyotis corymbosa (L.) Lamkleaves were dried and powdered in a blender, and then filtered to obtain powder. Second, the powder was macerated by putting it into a large column and soaking it with $96 \%$ ethanol with a macerator tool for $3 \times 24$ hours. Third, the solvent was removed and evaporated with a rotary vacuum evaporator at a $40^{\circ} \mathrm{C}$ to produce extracts. Fourth, extract obtained was then added with distilled water in the ratio 1: 1 .

Furthermore, cancer was created by giving benzopyrene in all groups of the samples. Benzoyrene used was in the form of solid powder at a dose of 8 $\mathrm{mg} / \mathrm{kg}$ dissolved in olivarum olium with a ratio of 2 : 11. ${ }^{6}$ The provision of benzoyrene was conducted by injection using a syringe with a depth of 2-3 $\mathrm{mm}$ on oral intrabuccal mucosa of those rats as many as $0.07 \mathrm{ml}$ for 4 weeks. After cancer was created in those rats, they were given Hedyotis corymbosa (L.) Lamk extract with distilled water in the treatment groups, namely Treatment Group 1 about 375 $\mathrm{mg} / \mathrm{kg}$, Treatment Group 2 about $750 \mathrm{mg} / \mathrm{kg}$, and Treatment Group 3 about $1500 \mathrm{mg} / \mathrm{kg}$. Meanwhile, Control Group was only given with aquadest. Those groups were injected two times every week. The extract was given orally as many as $0.17 \mathrm{ml}$ every day for 10 days. ${ }^{19}$

Finally, tissue fixation process was conducted in two stages. First, the tissue was soaked into Buffered Neutral Formalin solution (10\% BNF with pH 6.5 -7.5) with a ratio of 1:10. Second, the tissue was processed by using an auto technician. Paraffin blocks were cut with a thickness of $4 \mu$. Cancer cell proliferation and capillary examinationby using $\mathrm{HE}$ staining technique ("Hematoxyllin eosin"). Expression of caspase-3 used caspase-3 monoclonal 
antibody by Immunohistochemistry staining, counterstain was used as hematoxyllin.

\section{RESULTS}

This research had been approved with Ethical clearance from IEC of Dentistry Faculty, University of Airlangga. In this research, there were twentyfour mice suffering from mandibular gland cancer. Table 1 illustrated the average number of cancer cell proliferation in the control and treatment group.

Table 1. The average number of cancer cells in each group

\begin{tabular}{ccc}
\hline Group & Number of samples & Mean \\
\hline Control (negative) & 6 & 83.83 \\
$375 \mathrm{mg} / \mathrm{kg} \mathrm{BW}$ & 6 & 34.67 \\
$750 \mathrm{mg} / \mathrm{kg} \mathrm{BW}$ & 6 & 17.33 \\
$1500 \mathrm{mg} / \mathrm{kg} \mathrm{BW}$ & 6 & 43.17 \\
\hline
\end{tabular}

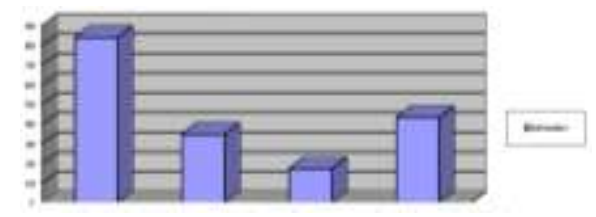

Graph 1 . The average number of cancer cells in lymph gland tissue

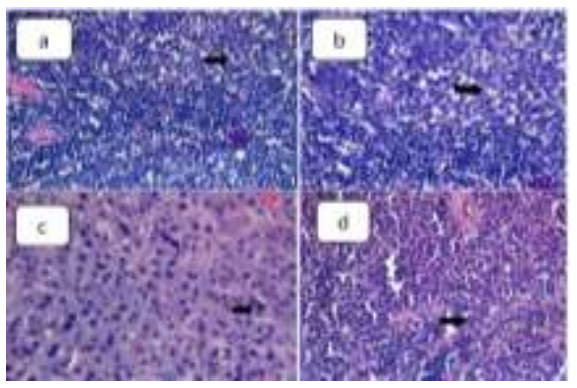

Figure 1. The average number of cancer cells shown with an Arrow, A. Control group, B. Treatment Group 1 (375 mg/kg BW), C. Treatment Group 2 (750 mg/kg BW), D. Treatment Group 3 ( $1500 \mathrm{mg} / \mathrm{kg} \mathrm{BW}$ )

Based on that data, it can be known that the average number of cancer cells in the control group was the highest one, while in the treatment group 2 was the lowest one compared to treatment group 1 and 3.

Table 2. The average number of new blood vessels in each group

\begin{tabular}{lcc}
\hline \multicolumn{1}{c}{ Group } & $\begin{array}{c}\text { Number of } \\
\text { samples }\end{array}$ & Mean \\
\hline Control Group & 6 & 54.33 \\
Treatment Group 1 $(375 \mathrm{mg} / \mathrm{kg} \mathrm{BW})$ & 6 & 32.33 \\
Treatment Group 2 $(750 \mathrm{mg} / \mathrm{kg} \mathrm{BW})$ & 6 & 21.83
\end{tabular}

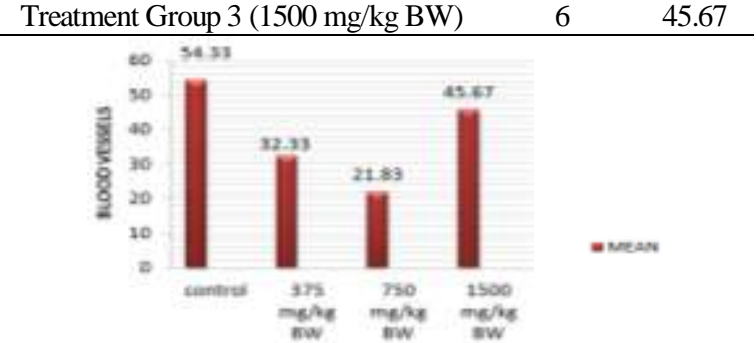

Graphic 2. The average number of new blood vessels in each group

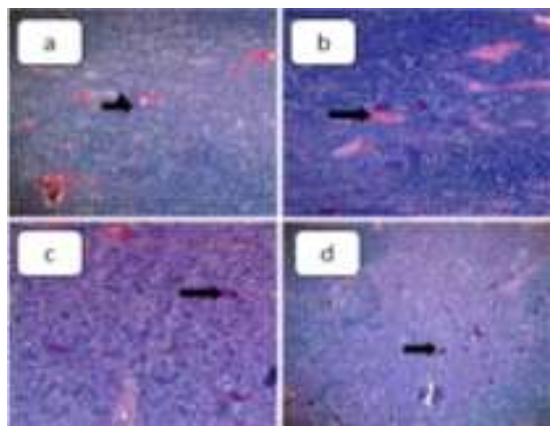

Figure 2. New blood vessels in three each groups shown with an Arrow (A. Control group, B. Treatment Group 1, C. Treatment Group 2, D. Treatment Group 3)

Based on Table 2, it can be seen that the average number of new blood vessels in the control group was more than the average number in the treatment groups. It can also be seen that the average number of new blood vessels in the treatment group 2 was the lowest one compared to the treatment Group 1 and 3.

In other words, it can be said that the ethanol extract of Hedyotis corymbosa (L.) Lamk can significantly inhibits the formation of new blood vessels in the treatment group 2 with a dose of $750 \mathrm{mg} / \mathrm{kg}$. Thus, the dose used in the treatment group 2 can be considered as the most influential dose compared to the treatment group with a dose of $375 \mathrm{mg} / \mathrm{kg}$ dose and the treatment group 3 with a dose $1500 \mathrm{mg} / \mathrm{kg}$.

Tables 3 and figure 3 show the average number of cancer cells expressing caspase-3 from all groups. Based on that table, it is known that the highest average number of cancer cells expressing caspase3 was in the apoptosis of the treatment group 2 .

Table 3. The average number of cells expressing caspase-3 in each group

\begin{tabular}{lc}
\hline \multicolumn{1}{c}{ Group } & $\begin{array}{c}\text { The average number of cells } \\
\text { expressing caspase-3 }\end{array}$ \\
\hline Control & 11.67 \\
Treatment Group 1 & 6.67 \\
Treatment Group 2 & 24.17
\end{tabular}




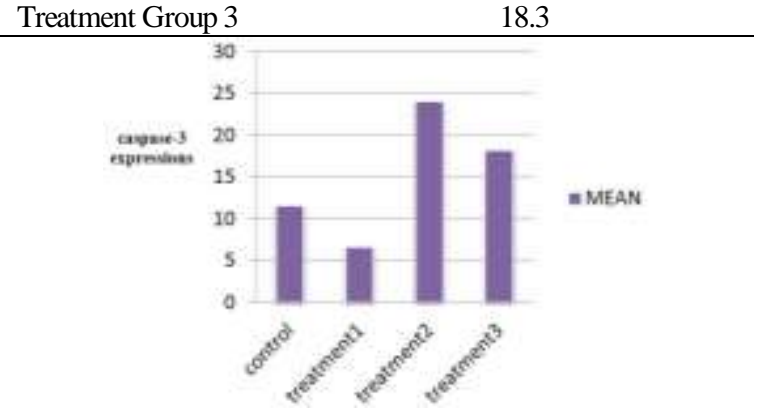

Graph 3. The average number of cells expressing caspase-3

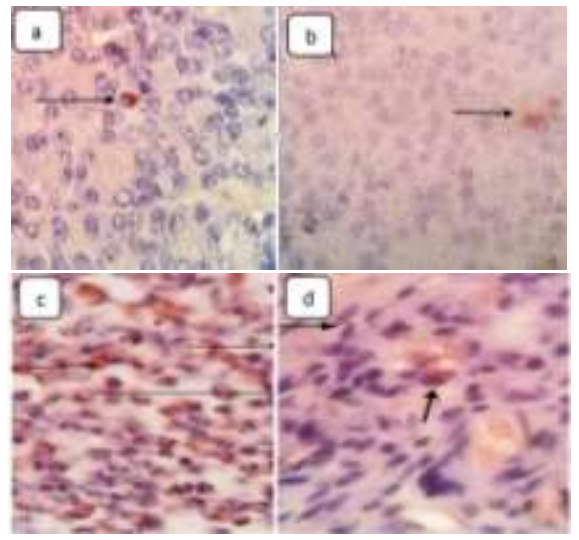

Figure 3. The Expression of caspase-3shown brown (an arrow) in the control group (a), treatment group 1 (b), treatment group 2 (c), treatment group 3 (c)

Then, the data obtained was tested by using the normal distribution of one-sample KolmogorovSmirnov test. Levene's homogeneity test method was then conducted to show whether the variant data was homogeneous or not with $\mathrm{p}=0240$ ( $\mathrm{p}>$ 0.05). Based on the results of one sample Kolmogorov-Smirnov test and Levene's homogeneity test, it is known that the distribution of the data obtained was normal and homogeneous. Thus, data was tested by using One-Way ANOVA. Finally, based on One-Way ANOVA test results, it is known that the value of $p=0.000(p<0.05)$. It means that there was significant difference. Therefore, Post Hoc Test was conducted by using Tukey HSD.

\section{DISCUSSION}

Cancer is considered as the leading cause of mortality and morbidity in the world. Cancer cells can invade biological tissues by invasion and metastasis. Abnormal protein function can lead to DNA damage and p53 gene mutation, controlling cell proliferation. Therefore, uncontrolled cell proliferation and inhibited apoptosis can lead to cancer. However, normal cells only will develop into cancer cells if the condition of the body's immune system decreases. In other words, the immune system will help the process of initiation, promotion and progression in cancer formation. ${ }^{17}$

This research, furthermore, is a purely experimental research aimed to know the benefits of Hedyotis corymbosa (L.) Lamk extract in preventing and curing cancer. According to Febriansah et al. ${ }^{3}$ Hedyotis corymbosa (L.) Lamk extract contained of ursolic acid playing anti-proliferative role against liver cancer cells. In addition, according to Jaki et al. ${ }^{11}$ ursolic acid also acted as an immunemodulatory, anti-inflammatory, and antioxidant. Therefore, it can be said that ursolic acid can be used in the development of cancer therapies.

In this research, cancer studied was formed in lymph gland. In accordance with the opinion, ${ }^{17}$ it is known that immune system has many effects on cancer incidence. Benzopyrene injected in this research is highly reactive compounds that can suppress the immune system. Therefore, it can lead to cancer in sub-mandibular gland.

Benzopyrene compound, moreover, is an organic compound with specific molecular formula, $\mathrm{C}_{20} \mathrm{H}_{12}$, including the class of polycyclic aromatic hydrocarbons $(P A H)$ that is extremely toxic. In the living body, benzopyrene does intercalation into Deoxyribo Nucleic Acid (DNA) that can interfere with the process of DNA transcription. Therefore, the disruption of the transcription process can serve as a tumor initiator and mediator.

Benzopyrene, furthermore, has structural similarities with nucleobases, namely adenosine, thymine, guanine and cytosine. This makes benzopyrene is easy to insert themselves into the DNA strands. ${ }^{18}$ As a result, the function of the DNA will be disturbed, and if the damage cannot be repaired, the cell will cause cancer.

It is also known that benzopyrene is hydrophobic, which does not have methyl structure or other reactive properties to be converted to a more polar compound. As a result, it is very difficult for the body to excrete this compound, causing accumulation in body tissues, such as lymph, adipose, liver and kidney tissue. Therefore, the exposure of benzopyrene in high level will cause the suppression of the immune system, and will also lead to cancer. ${ }^{19}$

After cancer was formed, Hedyotis corymbosa (L.) Lamk extract was given to KP1 for 10 days at a dose of $375 \mathrm{mg} / \mathrm{kg}, \mathrm{KP} 2$ with a dose of $750 \mathrm{mg} / \mathrm{kg}$, and $\mathrm{KP} 3$ with a dose $1,500 \mathrm{mg} / \mathrm{kg}$. Based on the $H P A$ examination, data for analysis was obtained. In general, the results showed that the average number 
of cancer cells in the group given with Hedyotis corymbosa (L.) Lamk extract was fewer than that in the group not given (Table 1). It is because of the role of Hedyotis corymbosa (L.) Lamk extractas anti-proliferation. It is also known that Hedyotis corymbosa (L.) Lamk extract contained of ursolic acid considered as an anti-proliferation of cancer cells by the inhibition of STAT3 (Signal Transducers and Activators of Transcription-3) pathway. ${ }^{20}$

Furthermore, ursolic acid will bind to estrogen receptors on the surface of macrophages, which then activates intracellular transduction signal causing the phosphorylation and degradation of $I k B$ (Inhibitor $k$ Beta). The degradation of $I k B$ can enable $N F-k B$ (Nuclear Factor Beta $k$ ) to translocateinto nucleus. In the nucleus, $N F-k B$ induces the transcription of genes that control various chemokines, immune receptors, and cytokines, such as $I L-12$. The induction of $I L-12$ will stimulate the production of $I F N-\gamma$, but can also prevent the proliferation of $T h 2$, which produces $I L-10$ as homeostasis.

Then, IFN- wwill re-activate macrophages that can lead to the phagocytes is of cancer cells. Meanwhile, the decreasing of $I L-10$ then will inhibit STAT3 path way. IL-10 is a cytokine that works on STAT3 path way. Thus, the decreasing of $I L-10$ can cause the inhibition of STAT3 pathway through JAK-2. Ursolic acidactually is able to inhibit JAK-2 (Janus Activated Kinase-2), so the phosphorylation of proteins used in the activation of STAT3 will not happen. The inhibition of STAT3 pathway then will lead to the disruption of the regulation system of gene products (such as cyclin Dl, Bcl-2, Bcl-xl, survivin, Mcl-1, and vascular endothelial growth factor) and the modulation of cell proliferation.

\section{REFERENCES}

1. Ariyani A. Uji sitotoksik isolat 1 dan 2 rumput mutiara (Hedyotis corymbosa (L.) Lamk.) terhadap sel kanker payudara T47D dan serviks HeLa. Journal Fakultas Matematika dan Ilmu Pengetahuan Alam Universitas sebelas maret Surakarta.2011: 3-9.

2. Syafriadi M. Patologi mulut tumor neoplastik dan non neoplastik rongga mulut. Yogyakarta. 2008: 74-7.

3. Febriansah. Ekstrak etanolik rumput mutiara (Hedyotis corymbosa) berefek antiproliferasi terhadap sel hepar tikus galur Sprague Dawley terinduksi 7,12-dimetil benz[a] antrazena melalui penghambatan ekspresi protein c-Myc. Prosiding Kongres Ilmiah XVI ISFI. Fakultas Farmasi UGM. 2008: 23-39.

4. Sudiono J. Pemeriksaan Patologi untuk Diagnosis Neoplasma Mulut. Jakarta: ECG. 2008: 50-70.
STAT3, moreover, is a signal transduction that acts as a regulatorof gene products, such as cyclin D1. Thus, the inactivation of STAT3 pathway will lead to the disruption of the nuclear translocation, so it is unable to play a role in regulating cyclin $D 1$ and modulating cell proliferation. Cyclin $D 1$ is an active form of Cyclin Dependent Kinase (CDK) needed by the cell to perform mitosis and play a role in $G 1$ phase. $G l$ phase is aimed to prepare DNA replication phase. Therefore, when this phase is interrupted, it can inhibit cell proliferation.

In the $G 1$ phase, furthermore, there was $p 53$ gene involved in the transactivation of the $p 21$ protein. The function of $p 21$ gene is to suppress the activity of $C D K$-Cyclin complexes, so check point occurs at the end of the $G 1$ phase before entering the $S$ phase. Check point is aimed to providean opportunity for the cell to repair or apoptosis. Apoptosis is characterized by the increasing of caspase-3 expression, known as the executor of cell death. The formation of new blood vessels then can be decreased by inhibiting ERK (Extra Celular Signal Regulatory Kinase), causing a decrease in HIF- $\alpha$ (hypoxia inducible factor). Finally, it causes VEGF barriers, so new blood vessels formed are few.

It can be concluded that ethanol extract of $\mathrm{He}$ dyotis corymbosa (L.) Lamkcan reduce the progression of oral cancer in the lymph gland of Wistar strain rats induced by benzopyrene with the best dose of $750 \mathrm{mg} / \mathrm{kg}$. Further research needs to use pure compound, ursolic acid, to decrease the progression of cancer in oral cavity. Additional research also needs to be conducted regarding the ability of ursolic acid in enhancing immune system as an immunomodulator.

5. Wang X, Zhang F. Ursolic acid inhibits proliferation and induces apoptosis of cancer cells in vitro and in vivo. J Biomed Biotech 2011; 3: 419-43.

6. Nagy JA, Chang SH, Dvorak AM, Dvorak HF. Why are tumour blood vessels abnormal and why is it important to know? British J. Cancer 2009; 866-7.

7. IPTEKnet. Tanaman Obat Indonesia, Rumput mutiara (Hedyotis corymbosa (L.) Lamk.). <http:// www.iptek.net.id/> (20 Februari 2010)

8. Murdiyono T. Uji toksisitas hasil fraksinasi daun rumput mutiara (Hedyotis corymbosa L. (Lamk.) terhadap Artemia Salina Leach dan Profil Kandungan Kimia Fraksi Teraktif. Skripsi. Jurusan Biologi Universitas Sebelas Maret, Surakarta. 2008: 2-12. 
9. Sukamdi D, Asyhar A, Jenie R. Peningkatan Ekspresi p53 oleh ekstrak etanolik rumput mutiara (Hedyotis Corymbosa) pada sel hepar tikus sprague dawley terinduksi 7, 12-Dimetilbenz(a) antra-sena. Pharmacon Journal. 2010; 11 (1): 2-4

10. Sadasivan, S. Hepatoprotective studies on Hedyotis Corymbosa (L.) Lamk. Journal of ethnopharmacology, 2006; 106: 245-9

11. Jaki B, Fanzblau S, Chadwick L, Lankin D, Zhang F, Wang Y. Purity Activity Relationships of Natural Products: The case of Anti-TB Active Ursolic Acid. J Nat Peod. 2008; 71: 1742-8

12. Prasad S, Yadaf R, Kannappan R, Aggarwal B. Ursolic acid, a pentacyclin triterpenne, potentiates TRAIL-inducied Apoptosis through p53-independent up-regulation of death receptors. <http://www. jbc.org/content/suppl/2010/12/14/M110.183699.DC 1.html> (28 Maret 2014).

13. Li W, Qiong L, Lin HE, Juan JB, Xiu FY. Effect of Ursolic Acid Extracted from Chinese Herbs on the Proliferation of Vascular Endhotelial Cells and Its Underlying Mechanism. J. of Med Plants Research. 2011; 5 (21): 5275

14. Fan, Guowei. Development of Traditional Chinese Medicine Extracts with Anti-Angiogenesis Property. Institute of Traditional Chinese Med. 2014; 1 (1): 3.
15. Mukmilah L, Udin Z, Lisnawati E. Uji aktivitas dari ekstrak rumput mutiara (Hedyotis corymbosa (L.) Lamk.). Valensi J. 2012; 2 (5): 548-56.

16. Budhy TI. Mekanisme nekrosis sel kanker oleh sel imunokompeten makrofag karena pemberian ekstrak teh hitam pada mukosa rongga mulut yang terpapar benzopirene. Surabaya LPPM Universitas Airlangga. 2000: 30-39.

17. Kumar V. Robbins Basic Pathologic, $7^{\text {th }}$ ed., Jakarta: Penerbit Buku Kedokteran ECG, 2007; 185-224.

18. Guo N, Faller DV, Vaziri C. Carcinogen induced Sphase arrest is Chk 1 medieted and caffeine sensitive. Cell Growth Differentiation. 2002; 13: 77-86.

19. Jung K, Patel M, Kinney P. Chillrud S, Whyatt R, Hoepner L. Effects of season and indoor heating on indoor and outdoor residential levels of airbone polycyclic aromatic hydrocarbons, absorbance and particulate matter 2.5 in an inner city cohort of young children. J. Allergy Clin. Immunol. 2010: 100-125.

20. Pathak A, Bhutani M, Nair A. Ursolic acid inhibits STAT-3 activation pathway leading to suppression of proliferation and chemosensitization of human multiple myeloma cells. Mol Cancer Res. 2007: 5-9. 